Article

\title{
Production of Renewable Hydrogen from Glycerol Steam Reforming over Bimetallic Ni-(Cu,Co,Cr) Catalysts Supported on SBA-15 Silica
}

\author{
Alicia Carrero, José A. Calles, Lourdes García-Moreno and Arturo J. Vizcaíno * \\ Department of Chemical and Energy Technology, ESCET, Rey Juan Carlos University, 28933 Móstoles, Spain; \\ alicia.carrero@urjc.es (A.C.); joseantonio.calles@urjc.es (J.A.C.); lourdes.garcia@urjc.es (L.G.-M.) \\ * Correspondence: arturo.vizcaino@urjc.es; Tel.: +34-91-488-8096
}

Academic Editor: Simon Penner

Received: 11 December 2016; Accepted: 6 February 2017; Published: 10 February 2017

\begin{abstract}
Glycerol steam reforming (GSR) is a promising alternative to obtain renewable hydrogen and help the economics of the biodiesel industry. Nickel-based catalysts are typically used in reforming reactions. However, the choice of the catalyst greatly influences the process, so the development of bimetallic catalysts is a research topic of relevant interest. In this work, the effect of adding $\mathrm{Cu}, \mathrm{Co}$, and $\mathrm{Cr}$ to the formulation of Ni/SBA- 15 catalysts for hydrogen production by GSR has been studied, looking for an enhancement of its catalytic performance. Bimetallic Ni-M/SBA-15 (M: $\mathrm{Co}, \mathrm{Cu}, \mathrm{Cr}$ ) samples were prepared by incipient wetness co-impregnation to reach $15 \mathrm{wt} \%$ of $\mathrm{Ni}$ and $4 \mathrm{wt} \%$ of the second metal. Catalysts were characterized by inductively coupled plasma atomic emission spectroscopy (ICP-AES), $\mathrm{N}_{2}$-physisorption, $\mathrm{X}$-ray powder diffraction (XRD), hydrogen temperature programmed reduction $\left(\mathrm{H}_{2}-\mathrm{TPR}\right)$, transmission electron microscopy (TEM), scanning electron microscopy (SEM), and thermogravimetric analyses (TGA), and tested in GSR at $600{ }^{\circ} \mathrm{C}$ and atmospheric pressure. The addition of $\mathrm{Cu}, \mathrm{Co}$, and $\mathrm{Cr}$ to the Ni/SBA-15 catalyst helped to form smaller crystallites of the Ni phase, this effect being more pronounced in the case of the Ni-Cr/SBA-15 sample. This catalyst also showed a reduction profile shifted towards higher temperatures, indicating stronger metal-support interaction. As a consequence, the Ni-Cr/SBA-15 catalyst exhibited the best performance in GSR in terms of glycerol conversion and hydrogen production. Additionally, $\mathrm{Ni}-\mathrm{Cr} / \mathrm{SBA}-15$ achieved a drastic reduction in coke formation compared to the Ni/SBA-15 material.
\end{abstract}

Keywords: nickel; copper; cobalt; chromium; mesoporous silica; promoter; steam reforming; hydrogen; glycerin

\section{Introduction}

Current energy and environmental policies are inextricably linked and focus on reducing $\mathrm{CO}_{2}$ emissions and ensuring energy supply [1]. In the search for alternatives to fossil fuels, hydrogen is presented as the energy vector of the future. It has promising applications in transport and power generation because it has the highest energy content per unit mass in comparison with other fuels. In addition, only water and energy are produced when hydrogen is used as a fuel, and it may be obtained from a great variety of renewable raw materials and energy resources [2,3]. Today, hydrogen is mainly produced from the thermochemical conversion of fossil fuels at high pressures and temperatures, particularly by steam reforming of natural gas, which is associated with various environmental issues related to greenhouse gases. In this context, alcohols derived from biomass, like methanol [4], ethanol [3,5], or glycerol [6-8] may also be reformed to generate hydrogen, turning reforming into a zero net carbon emissions process. 
Taking into account that glycerol is a by-product of the growing biodiesel industry, glycerol production has significantly increased in the last years and saturated the market, causing prices to go into free fall $[9,10]$. In this context, the catalytic steam reforming of this glycerol could be an interesting way to produce hydrogen from a relatively inexpensive feedstock. At the same time, problems related to the disposal of the increasing excess of glycerin and the economics of the biodiesel industry would be alleviated.

Glycerol steam reforming is an endothermic catalytic process that can be represented as follows:

$$
\mathrm{C}_{3} \mathrm{H}_{8} \mathrm{O}_{3}+3 \mathrm{H}_{2} \mathrm{O} \leftrightarrow 3 \mathrm{CO}_{2}+7 \mathrm{H}_{2} \quad \Delta \mathrm{H}^{\circ}=128 \mathrm{~kJ} / \mathrm{mol}
$$

Since the reaction is favored by temperature, an optimum high value is normally determined by thermodynamic studies [11,12]. However, high temperatures are not favorable from the economic point of view. In addition, the steam reforming of oxygenated compounds is usually affected by the formation of by-products, reducing the selectivity to hydrogen and leading to coke formation $[7,13,14]$. Theoretically, water/glycerol feed ratios higher than 5 allow the inhibition of carbon formation [12], although too high amounts of water would imply higher reactor volume and excessive vaporization costs at the industrial scale. In such a condition, the concentration of hydrogen tends to be stable above $850 \mathrm{~K}$ [11]. Thus, glycerol steam reforming is typically carried out between $500{ }^{\circ} \mathrm{C}$ and $700{ }^{\circ} \mathrm{C}$ [13].

Catalysts for steam reforming processes are currently a research subject, mainly focused on the improvement of the catalytic activity, the selectivity to hydrogen, and the resistance to coke formation. This last issue is one of the main problems for catalyst deactivation, together with sintering of metal particles. Different supported metals have been investigated as catalysts for steam reforming, mainly nickel, cobalt, and noble metals [14-17]. Concretely, nickel-based catalysts have demonstrated high activity in reforming reactions. In addition, the low cost and availability of nickel in comparison with noble metals have led to the widespread use of nickel-based catalysts for steam reforming. Several studies [18-28] have been published on the use of bimetallic catalysts for different reactions to obtain the advantages of each component, since the modification of the active surface metal by the presence of other metals can improve $\mathrm{Ni}$ dispersion and resistance to deactivation.

Tuan et al. [18] have recently reported that the addition of copper can increase the dispersion of nickel in $\mathrm{Cu}-\mathrm{Ni} / \mathrm{Al}_{2} \mathrm{O}_{3}$ catalysts and can facilitate the reduction of $\mathrm{Ni}$ at low temperature, improving the catalytic performance in the low-temperature gasoline reforming. We also showed that although $\mathrm{Ni}$ is responsible for $\mathrm{H}_{2}$ production from ethanol steam reforming, $\mathrm{CO}$ generation and coke deposition could be decreased with the addition of certain loadings of $\mathrm{Cu}[19,20]$. On the other hand, Hossain et al. [21] stated that the addition of $\mathrm{Co}$ enhances the reducibility of nickel species in the $\mathrm{Ni} / \mathrm{Al}_{2} \mathrm{O}_{3}$ oxygen carrier for a chemical-looping combustion process by influencing the metal-support interactions, and it inhibited agglomeration of metal particles. As a consequence $\mathrm{Co}-\mathrm{Ni} / \mathrm{Al}_{2} \mathrm{O}_{3}$ displayed excellent reactivity and stability. Shen and Chen [22] found that doping $\mathrm{Co}$ in $\mathrm{NiB}$ decreased the particle size and increased the stability of the $\mathrm{NiCoB}$ amorphous nanoalloy catalysts for hydrogenation of p-chloronitrobenzene. Several studies [23-26] have shown that Ni-Co bimetallic catalysts are able to significantly decrease carbon deposition during the reforming reactions of different feedstocks (acetic acid, biogas or cellulose). Moreover, García et al. [27] stated that incorporation of Co and $\mathrm{Cr}$ to $\mathrm{Ni} / \mathrm{MgOLa}_{2} \mathrm{O}_{3}$ modified the metal sites forming alloys with nickel and possibly reducing the crystallite size, so improving its performance in the steam reforming of bio-oil. $\mathrm{Cr}$ has also been used as a promoter of $\mathrm{Ni}-\mathrm{Cr} / \mathrm{yttria}$-doped ceria in the dry methane reforming [28] and was found to be beneficial to the dilution of the ensembles of $\mathrm{Ni}$ atoms and to the stability of the catalyst.

Much of the above-mentioned studies used alumina as the support of the active metals. However, in steam reforming of oxygenated hydrocarbons, the choice of the support is important in order to avoid dehydration reactions favored on acidic sites, which lead to increased carbon formation $[29,30]$. In this sense, the use of silica-based materials, especially SBA-15, as a carrier in reforming catalysts, has been demonstrated to lead to good results [19]. SBA-15 is a siliceous material characterized by a highly-ordered porous structure with two-dimensional hexagonal symmetry formed by uniform 
and elongated channels, with outstanding thermal stability, pore size adjustment, and tailored particle morphology [31]. Large surface area and mesoporous structure of the support have been demonstrated to play an important role in improving Ni dispersion and in suppressing Ni sintering [19,32].

To go further, the aim of this work is the synthesis of bimetallic Ni-M/SBA-15 (M: Co, Cu, Cr) catalysts for glycerol steam reforming, attempting to enhance the catalytic performance of Ni/SBA-15 in terms of glycerol conversion, hydrogen production and coke resistance. Materials were characterized by inductively coupled plasma atomic emission spectroscopy (ICP-AES), $\mathrm{N}_{2}$-physisorption, $\mathrm{X}$-ray powder diffraction (XRD), hydrogen temperature programmed reduction $\left(\mathrm{H}_{2}-\mathrm{TPR}\right)$, transmission electron microscopy (TEM), scanning electron microscopy (SEM), and thermogravimetric analyses (TGA), in order to relate their catalytic activity with their physico-chemical properties. To date, only a few studies have been published about the use of Ni/SBA-15 in glycerol steam reforming $[7,33,34]$. These bimetallic materials are novel catalysts for glycerol steam reforming.

\section{Results and Discussion}

\subsection{Characterization of Catalysts}

The physico-chemical properties of the catalysts prepared in this work are summarized in Table 1. Metal content measured by ICP-AES was checked to be near the nominal loadings of $15 \mathrm{wt} \%$ of Ni and $4 \mathrm{wt} \%$ of $\mathrm{Cr}, \mathrm{Cu}$, or $\mathrm{Co}$.

Table 1. Physico-chemical properties of the Ni-(Cu,Co,Cr)/SBA-15 catalysts.

\begin{tabular}{|c|c|c|c|c|c|c|c|}
\hline Sample & $\mathrm{Ni}(w t \%)$ & $M^{1}\left(w t^{\%}\right)$ & $S_{\text {BET }}\left(\mathrm{m}^{2} \cdot \mathrm{g}^{-1}\right)$ & $V_{\text {pore }}{ }^{2}\left(\mathrm{~cm}^{3} \cdot \mathrm{g}^{-1}\right)$ & $D_{\text {pore }}{ }^{3}(\mathrm{~nm})$ & $\mathrm{D}_{\mathrm{NiO}}{ }^{4}(\mathrm{~nm})$ & $\mathrm{D}_{\mathrm{Ni}}{ }^{5}(\mathrm{~nm})$ \\
\hline Ni/SBA-15 & 14.5 & - & 521 & 0.77 & 8.3 & 9.6 & 10.6 \\
\hline $\mathrm{Ni}-\mathrm{Cu} / \mathrm{SBA}-15$ & 15.0 & 4.0 & 485 & 0.71 & 8.1 & 8.6 & 9.9 \\
\hline $\mathrm{Ni}-\mathrm{Cr} / \mathrm{SBA}-15$ & 14.3 & 3.6 & 482 & 0.68 & 8.3 & 5.4 & 5.8 \\
\hline
\end{tabular}

${ }^{1} \mathrm{M}$ : Second metal $(\mathrm{Cu}, \mathrm{Co}$ or $\mathrm{Cr}) ;{ }^{2}$ Determined at $\mathrm{P} / \mathrm{P}_{0}=0.97 ;{ }^{3}$ Maximum of the BJH pore size distribution; ${ }^{4}$ Calculated from the (2 00 ) reflection of $\mathrm{NiO}$ in XRD of calcined catalysts; ${ }^{5}$ Calculated from the $\left(\begin{array}{llll}1 & 1 & 1\end{array}\right)$ reflection of $\mathrm{Ni}$ in XRD of reduced catalysts.

As shown in Figure 1A, all materials exhibited type IV isotherms, which are typical of the support used, SBA-15, which is a mesostructured material with a high specific surface area and narrow pore size distribution (see Figure 1B). According to Table 1, the incorporation of $\mathrm{Co}, \mathrm{Cr}$, or $\mathrm{Cu}$ into the formulation of the Ni/SBA-15 led to a slight decrease in the values of the textural properties $\left(\mathrm{S}_{\mathrm{BET}}\right.$, pore volume, and pore diameter) due to the inclusion of these metals within the porous structure of the support. In general, this reduction of the textural properties values of the bimetallic catalysts is lower than $10 \%$ with respect to the $\mathrm{Ni} / \mathrm{SBA}-15$ sample, which is considered to have poor influence in the catalytic activity of these materials.

Figure 2 shows the low-angle XRD patterns of calcined (A) and reduced (B) catalysts. An intense main peak and two additional weaker reflections can be observed for all samples. These peaks are assigned to (100), (110), and (200) plane reflections, respectively, characteristics of the hexagonal pore mesostructure of the SBA-15 material. This indicates that the structure of the support has been maintained after the metallic phase incorporation and the thermal processes (calcination and reduction), although the peak intensities are slightly reduced for the catalysts in comparison with the bare support. 


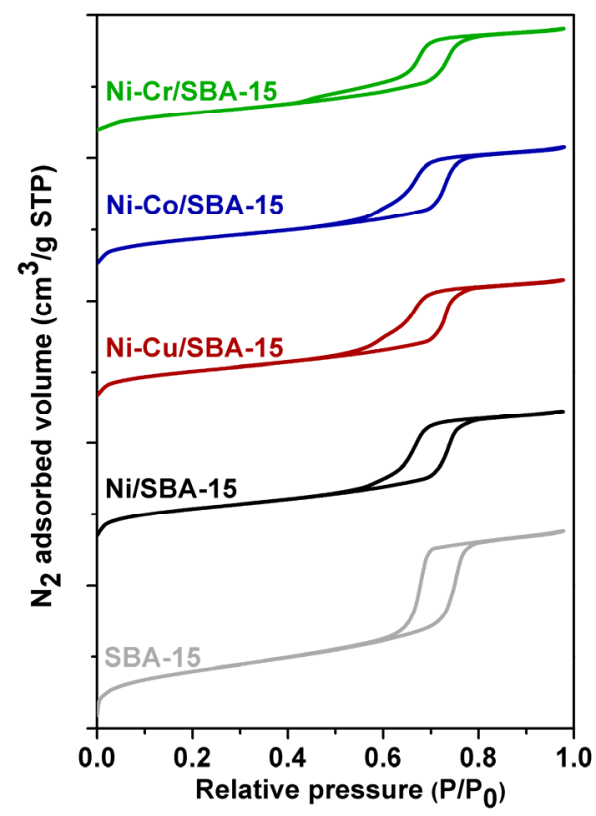

(A)

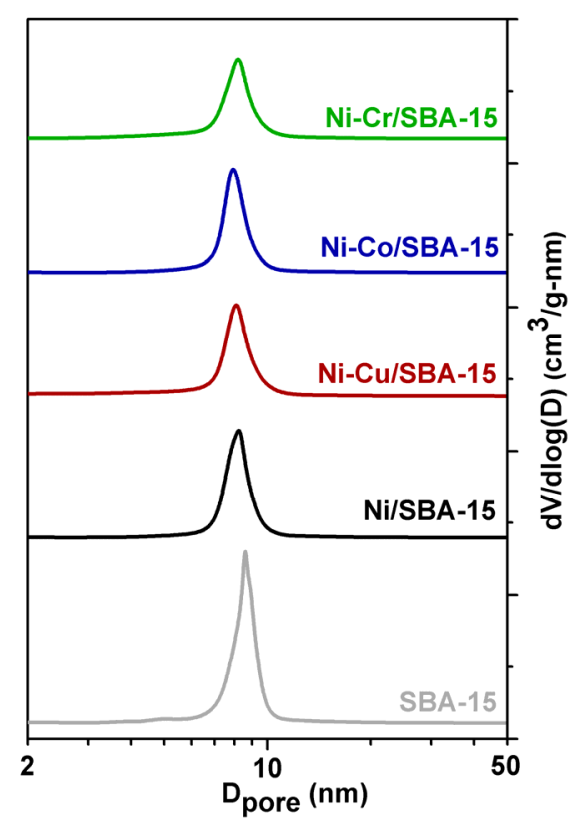

(B)

Figure 1. $\mathrm{N}_{2}$ adsorption-desorption at $77 \mathrm{~K}$ of SBA-15 support and the $\mathrm{Ni}-(\mathrm{Cu}, \mathrm{Co}, \mathrm{Cr}) / \mathrm{SBA}-15$ catalysts: (A) isotherms; and (B) pore size distribution.

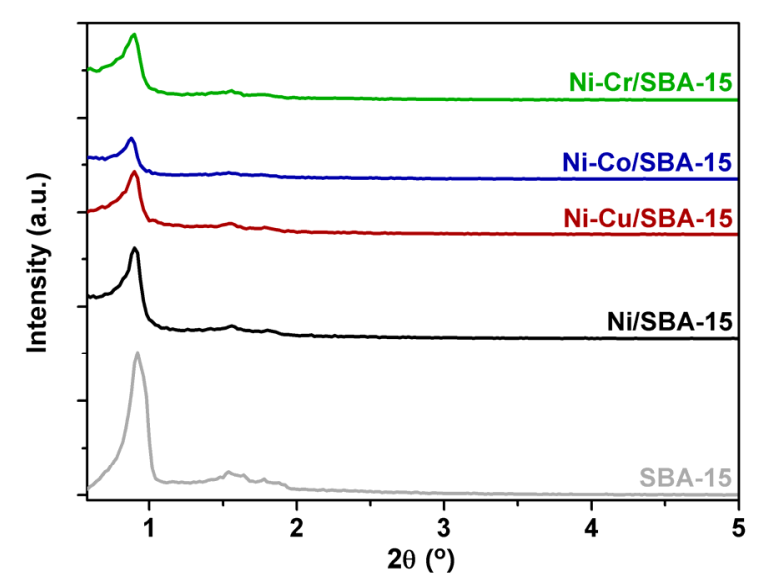

(A)

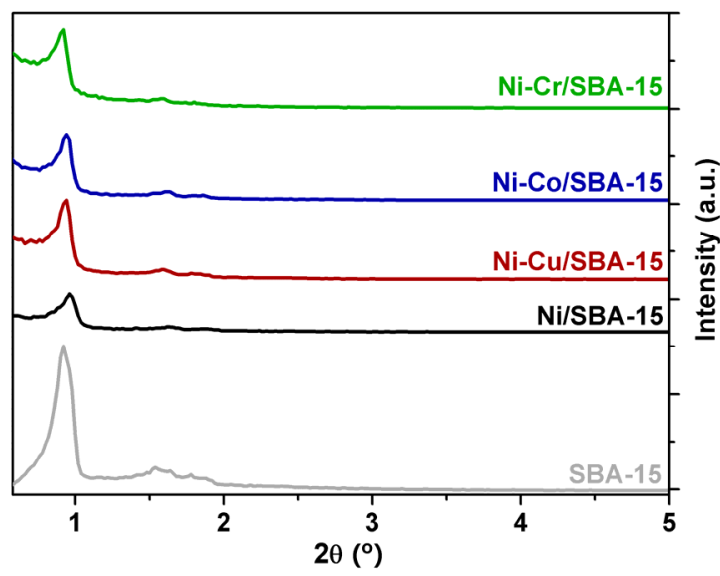

(B)

Figure 2. Small-angle X-ray diffraction of SBA-15 support and the Ni-(Cu,Co,Cr)/SBA-15 catalysts: (A) calcined; and (B) reduced.

Figure 3A shows the high-angle XRD patterns of calcined catalysts. Characteristic peaks of $\mathrm{NiO}$ appear at $2 \theta=37.3^{\circ}, 43.3^{\circ}, 62.9^{\circ}, 75.5^{\circ}$, and $79.5^{\circ}$ (JCPDS 78-0643). Furthermore, in the case of Ni-Co/SBA-15 catalyst, small peaks are also observed at $2 \theta=31.3^{\circ}, 36.9^{\circ}, 44.8^{\circ}, 59.4^{\circ}$, and $65.2^{\circ}$, indicating the presence of $\mathrm{Co}_{3} \mathrm{O}_{4}$ crystallites (JCPDS 42-1467). For Ni-Cr/SBA-15 and Ni-Cu/SBA-15 samples, peaks corresponding to $\mathrm{Cr}$ and $\mathrm{Cu}$ oxides are absent due to both the good dispersion of these metals in the catalysts and the detection limit of the crystal size provided by this technique, as observed elsewhere for similar materials [20,35]. Moreover, comparing the XRD patterns of the different catalysts, it is observed that $\mathrm{NiO}$ peaks in Ni/SBA-15 sample are more intense than in the catalysts doped with $\mathrm{Co}, \mathrm{Cr}$, or $\mathrm{Cu}$, indicating that $\mathrm{Ni}$ crystallites are smaller in the modified catalysts. 


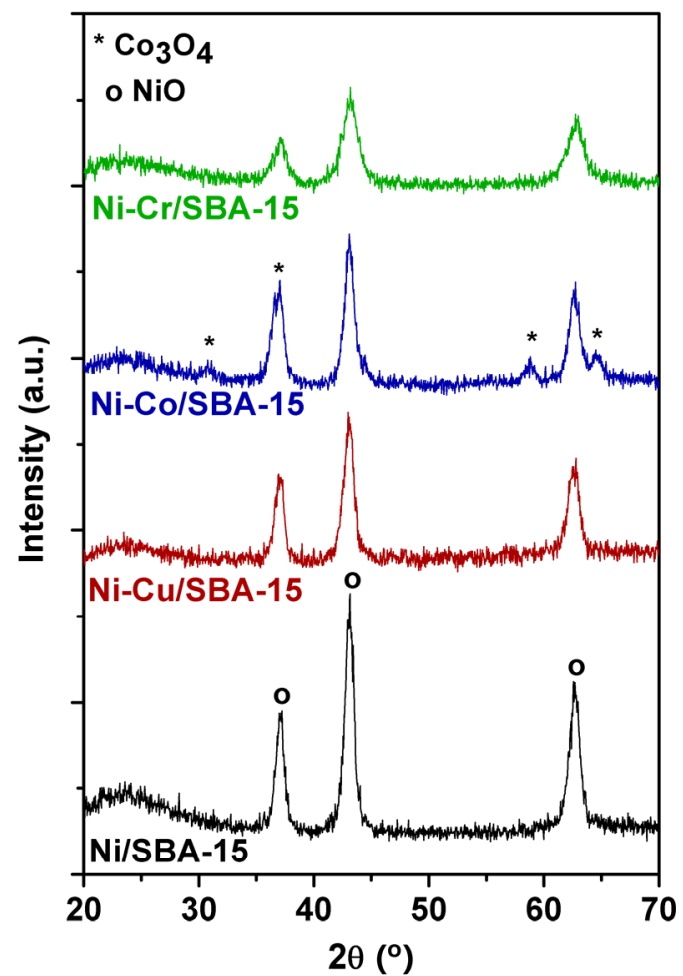

(A)

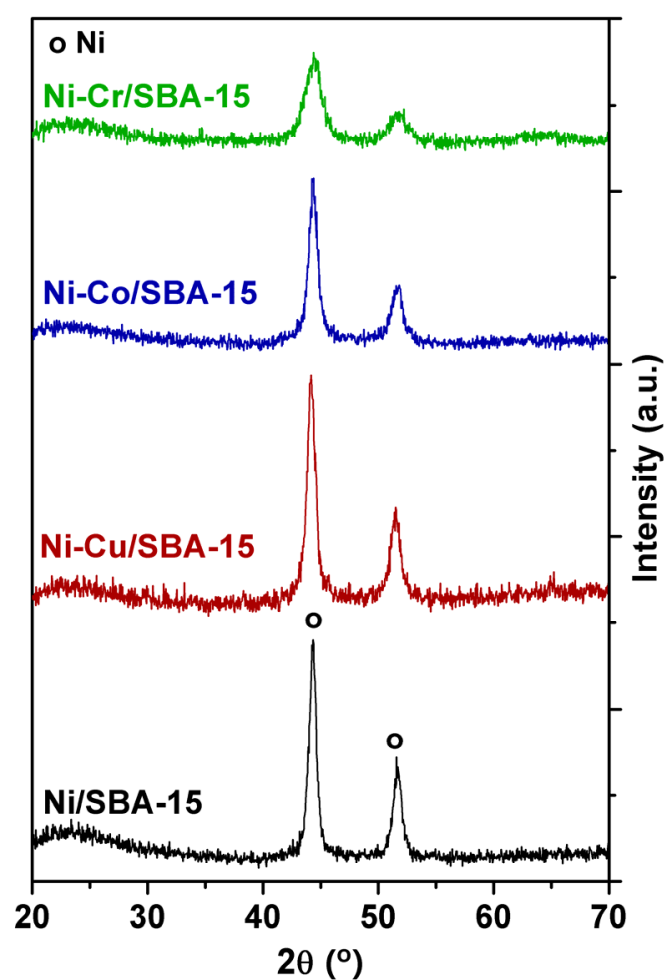

(B)

Figure 3. Wide-angle X-ray diffraction of the $\mathrm{Ni}-(\mathrm{Cu}, \mathrm{Co}, \mathrm{Cr}) / \mathrm{SBA}-15$ catalysts and the support: (A) calcined; and (B) reduced.

The high-angle XRD patterns of the reduced catalysts are shown in Figure 3B. It can be seen that the peaks corresponding to $\mathrm{NiO}$ have disappeared, while peaks at $2 \theta=44.5^{\circ}, 51.8^{\circ}$, and $76.3^{\circ}$, corresponding to metallic $\mathrm{Ni}^{0}$ (JCPDS 04-0850), are now observed as a consequence of the reduction process. In this case, peaks corresponding to $\mathrm{Co}_{3} \mathrm{O}_{4}$ are not observed, probably indicating the reduction of this species. However, reflections corresponding to metallic $\mathrm{Co}^{0}$ (JCPDS 15-0806) cannot be distinguished since they overlap with those of metallic $\mathrm{Ni}^{0}$. As in the case of the calcined catalysts, diffraction lines corresponding to both $\mathrm{Cu}$ and $\mathrm{Cr}$ phases are not observed. It must be noted that $\mathrm{Ni}^{0}$ peaks are less intense in the case of bimetallic catalysts again, indicating that the crystallites of the $\mathrm{Ni}$ phase are still smaller after the reduction process in comparison with $\mathrm{Ni}$ /SBA- 15 sample.

The crystallite sizes of Ni calculated by the Scherrer equation from XRD patterns are shown in Table 1 for both calcined and reduced catalysts, verifying that the addition of $\mathrm{Cu}, \mathrm{Co}$, and mainly $\mathrm{Cr}$ leads to bimetallic catalysts with the Ni phase more dispersed than in the initial Ni/SBA-15 sample.

In Figure 4, TEM micrographs of the calcined samples show the metal oxides particles (dark zones) over the hexagonal mesoporous structure of SBA-15 support. In the case of the bimetallic catalysts, energy dispersive $\mathrm{X}$-ray spectroscopy (EDX) microanalysis revealed the presence of $\mathrm{Ni}$ and the corresponding metal $(\mathrm{Cu}, \mathrm{Cr}$, or $\mathrm{Co})$ in the whole samples. Ni/SBA-15, Ni-Cu/SBA-15, and $\mathrm{Ni}-\mathrm{Co} / \mathrm{SBA}-15$ catalysts contain metal oxides particles with different sizes, the smallest of which show an irregular shape that seems to adapt to the support porosity, while the rest are placed over the external surface of the support. Larger particles predominate on the Ni/SBA-15 sample, while small particles inside the support porous structure are found in larger proportion in the Ni-Co/SBA-15 sample, in agreement with the XRD results. However, in the case of the Ni-Cr/SBA-15 catalyst the metal oxide particles are clearly more dispersed than in the rest of catalysts, so that almost no particle can be observed on the external surface of the support and only small particles could be found inside the SBA-15 channels. This is in accordance with the NiO crystallites size measured by XRD being smaller than the pore size in this sample (see Table 1). 


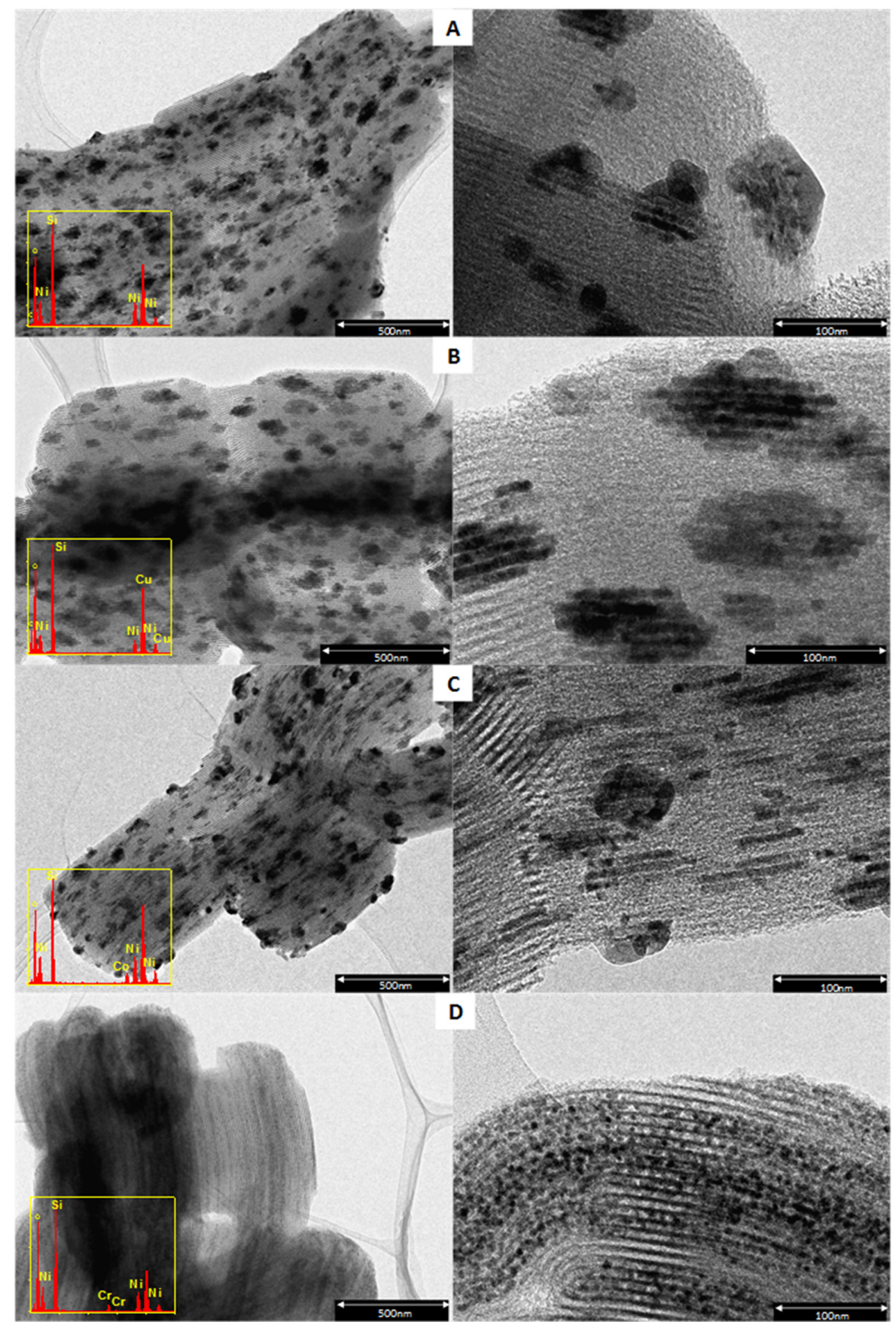

Figure 4. TEM images of the calcined catalysts: (A) Ni/SBA-15; (B) Ni-Cu/SBA-15; (C) Ni-Co/SBA-15; and (D) Ni-Cr/SBA-15.

The $\mathrm{H}_{2}$-TPR profiles of the prepared catalysts are shown in Figure 5A. In the case of the Ni/SBA-15 sample, the profile shows that $\mathrm{NiO}$ reduction occurs over a wide temperature range between $250{ }^{\circ} \mathrm{C}$ and $500{ }^{\circ} \mathrm{C}$. Three maxima can be distinguished at about $288^{\circ} \mathrm{C}, 345^{\circ} \mathrm{C}$, and $447{ }^{\circ} \mathrm{C}$, which can be assigned to different $\mathrm{NiO}$ particles whose interaction degree with the support is proportional to the temperature increase and inversely proportional to their crystallite sizes. Thus, above $400{ }^{\circ} \mathrm{C}$, small nickel oxide species with a strong interaction with the support are reduced. A similar TPR profile was obtained for a $\mathrm{Ni}(7 \mathrm{wt} \%) / \mathrm{SBA}-15$ sample in a previous work [17], with two reduction features centered around $345^{\circ} \mathrm{C}$ and $440^{\circ} \mathrm{C}$. Since the nominal $\mathrm{Ni}$ content of the Ni/SBA-15 sample prepared 
in the present work is higher ( $15 \mathrm{wt} \%$ ), the reduction zone around $288^{\circ} \mathrm{C}$ can be ascribed to relatively big agglomerates of $\mathrm{NiO}$ with weak interaction with the SBA-15 support.

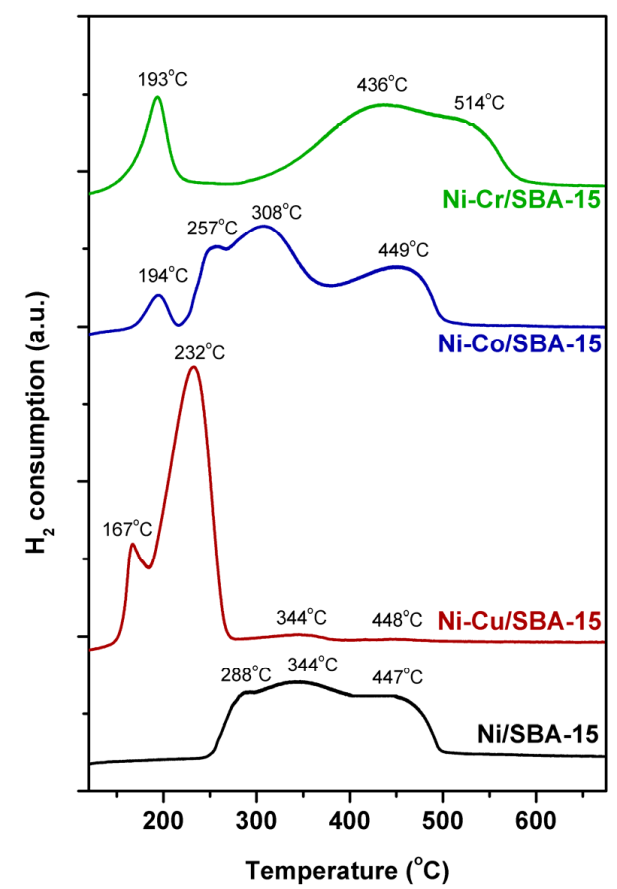

(A)

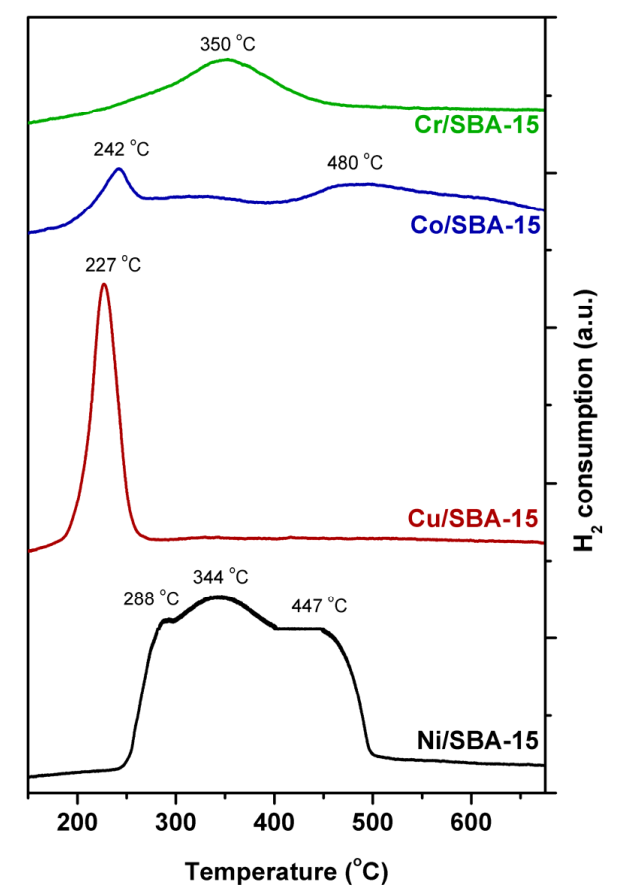

(B)

Figure 5. TPR profiles: (A) Ni-(Cu,Co,Cr)/SBA-15 catalysts; and (B) monometallic samples.

The reduction profiles of the bimetallic catalysts are quite different from that of the Ni/SBA-15 sample. Taking into account the complexity of the analysis of the reduction process when two metals are present in the sample, we prepared monometallic (4 wt \%) Cu/SBA-15, Co/SBA-15, and Cr/SBA-15 samples to be analyzed by TPR (Figure $5 \mathrm{~B}$ ). The reduction profile of the $\mathrm{Cu} / \mathrm{SBA}-15$ sample shows that reduction of $\mathrm{CuO}$ occurs around $227^{\circ} \mathrm{C}$, in agreement with the easier reduction of $\mathrm{CuO}$ in comparison to $\mathrm{NiO}$ [19]. In the case of the Co/SBA-15 sample, two main reduction zones can be defined: one at lower temperature with maximum around $242{ }^{\circ} \mathrm{C}$ and a shoulder below $400{ }^{\circ} \mathrm{C}$, due to the reduction of $\mathrm{Co}_{3} \mathrm{O}_{4}$ to $\mathrm{CoO}$ followed by the reduction of $\mathrm{CoO}$ to $\mathrm{Co}^{0}$; and another zone at high temperature (around $480{ }^{\circ} \mathrm{C}$ ) corresponding to the reduction of cobalt species with strong interaction with the support. Finally, the TPR profile of $\mathrm{Cr} / \mathrm{SBA}-15$ sample indicates that chromium oxide reduction occurs at $350^{\circ} \mathrm{C}$ in a single step, similarly to the observations made by Wang et al. for $\mathrm{Cr}$ supported on yttria-doped ceria [28].

According to this, the TPR results of the bimetallic catalysts, shown in Figure 5A, can be analyzed as follows. In the case of the Ni-Cu/SBA-15 catalyst, a major reduction zone can be observed at low temperature $\left(150-275^{\circ} \mathrm{C}\right)$, composed by two peaks with maxima at $167^{\circ} \mathrm{C}$ and $232^{\circ} \mathrm{C}$, which can be assigned the reduction of $\mathrm{CuO}$ and $\mathrm{NiO}$, respectively. Such a significant decrease in the reduction temperature of $\mathrm{NiO}$ by the presence of $\mathrm{CuO}$ has been previously observed [19] and ascribed to both a synergistic interaction between the oxide phases and a decrease of the crystallite sizes. Reduction zones around $344^{\circ} \mathrm{C}$ and $448^{\circ} \mathrm{C}$ are still present in this sample, as in the case of Ni/SBA-15, but with negligible extent.

In the wide TPR profile of the Ni-Co/SBA- 15 catalyst, four reduction bands can be distinguished with maxima at $194{ }^{\circ} \mathrm{C}, 257{ }^{\circ} \mathrm{C}, 308{ }^{\circ} \mathrm{C}$ and $449^{\circ} \mathrm{C}$. A synergic effect between nickel and cobalt species has been described to decrease the reduction temperature of these metal oxides in bimetallic catalysts [36]. Thus, peaks below $400{ }^{\circ} \mathrm{C}$ can be assigned to the reduction of $\mathrm{Co}_{3} \mathrm{O}_{4}$ and $\mathrm{NiO}$ particles weakly interacting with the SBA- 15 (analogous to reduction zone below $400{ }^{\circ} \mathrm{C}$ of the corresponding 
monometallic samples), which have been clearly affected by the above-mentioned synergic effect. However, this effect is less pronounced than in the case of the Ni-Cu/SBA-15 sample. Regarding the reduction zone at $449^{\circ} \mathrm{C}$, it corresponds to the reduction of small nickel (and cobalt) oxide species with a strong interaction with the support. The fact that this temperature results unchanged in comparison to the Ni/SBA-15 sample may be due to the opposed effects of smaller NiO crystallites (see Table 1), which would mean closer contact with the support, and the decrease of the NiO reduction temperature by the presence of Co.

Finally, the TPR profile corresponding to the Ni-Cr/SBA-15 catalyst displays two clearly differentiated reduction zones. According to Yun et al. [37], the low temperature peak (around $193^{\circ} \mathrm{C}$ ) can be attributed to the reduction of chromium oxide species affected by the presence of $\mathrm{Ni}$, while the high temperature zone corresponds to the reduction of nickel oxide. Thus, in comparison to the rest of samples, the reduction of nickel oxide in the Ni-Cr/SBA- 15 catalyst is shifted to higher temperatures, and even a new feature can be observed around $514^{\circ} \mathrm{C}$, ascribed to the reduction of amorphous dispersive nickel oxide species [28], in agreement with the small $\mathrm{NiO}$ crystallites found in this samples (see Table 1 and Figure 4).

Summing up, the incorporation of $\mathrm{Co}$ and especially $\mathrm{Cu}$ to Ni/SBA-15 led to the development of metal oxide species with lower reduction temperatures, while the $\mathrm{Ni}-\mathrm{Cr} / \mathrm{SBA}-15$ sample exhibited a broad profile at high temperatures with reduction features above $500{ }^{\circ} \mathrm{C}$.

\subsection{Catalytic Test on Glycerol Steam Reforming}

The above-described catalysts, were tested in the glycerol steam reforming at $600{ }^{\circ} \mathrm{C}$, using a steam $/$ carbon ratio $=2$ and a $\mathrm{WHSV}_{\text {glycerol }}=7.7 \mathrm{~h}^{-1}$. The catalytic results are shown in Figure 6, in terms of glycerol conversion, and in Table 2, in terms of composition of the gaseous products stream. All catalysts maintained glycerol conversions above $85 \mathrm{~mol} \%$ after five hours on stream, leading to hydrogen contents above $50 \mathrm{~mol} \%$ in the gas stream. Condensable products were also collected and analyzed along time-on-stream (TOS), verifying small formation of intermediates, (acrolein, propyleneglycol, hydroxyacetone, ethylene glycol, methanol, acetaldehyde, acetic acid, acetone, and ethanol) in a total concentration lower than $1.4 \mathrm{wt} \%$.

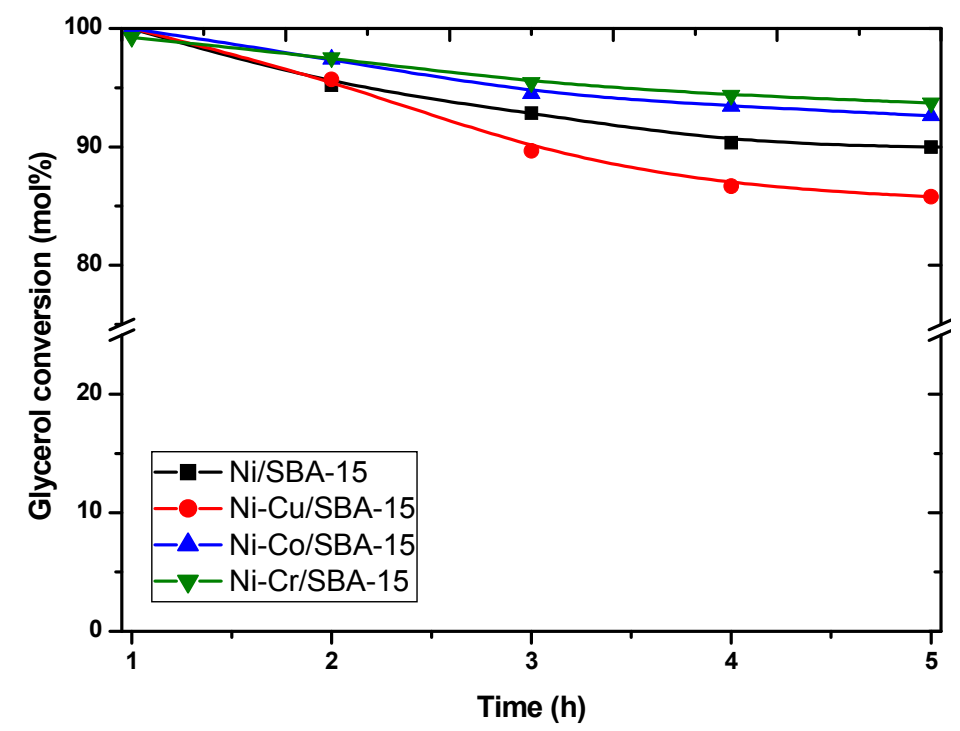

Figure 6. Conversion of glycerol over the $\mathrm{Ni}-(\mathrm{Cu}, \mathrm{Co}, \mathrm{Cr}) / \mathrm{SBA}-15$ catalysts $\left(T=600{ }^{\circ} \mathrm{C}, P=1 \mathrm{bar}\right.$, WHSV $_{\text {glycerol }}=7.7 \mathrm{~h}^{-1}$; water $/$ glycerol $=6 \mathrm{~mol} / \mathrm{mol}$ ) 
Table 2. Gas products distribution and coke formation in glycerol steam reforming using $\mathrm{Ni}-(\mathrm{Cu}, \mathrm{Co}, \mathrm{Cr}) / \mathrm{SBA}-15$ catalysts $\left(T=600{ }^{\circ} \mathrm{C}, P=1 \mathrm{bar}, \mathrm{WHSV}_{\text {glycerol }}=7.7 \mathrm{~h}^{-1}\right.$; water $/$ glycerol $=$ $6 \mathrm{~mol} / \mathrm{mol}$, TOS: $5 \mathrm{~h}$ ).

\begin{tabular}{|c|c|c|c|c|c|}
\hline \multirow{2}{*}{ Catalyst } & \multicolumn{4}{|c|}{ Gas Composition (mol \%) } & \multirow{2}{*}{$\begin{array}{c}\mathrm{C}_{\mathrm{dep}} \\
\left(\mathrm{mg}_{\text {coke }} / \mathrm{g}_{\text {cat }} \cdot \mathrm{h}\right)\end{array}$} \\
\hline & $\mathrm{H}_{2}$ & $\mathrm{CH}_{4}$ & $\mathrm{CO}_{2}$ & $\mathrm{CO}$ & \\
\hline Ni/SBA-15 & 54.5 & 1.4 & 35.1 & 9.0 & 126 \\
\hline $\mathrm{Ni}-\mathrm{Cu} / \mathrm{SBA}-15$ & 50.6 & 3.6 & 23.5 & 22.3 & 221 \\
\hline $\mathrm{Ni}-\mathrm{Co} / \mathrm{SBA}-15$ & 52.2 & 3.5 & 25.3 & 19.0 & 22 \\
\hline $\mathrm{Ni}-\mathrm{Cr} / \mathrm{SBA}-15$ & 61.4 & 1.2 & 26.6 & 10.8 & 13 \\
\hline
\end{tabular}

Regarding glycerol conversion, Figure 6 shows higher activity along time of Ni-Co/SBA-15 and $\mathrm{Ni}-\mathrm{Cr} / \mathrm{SBA}-15$ catalysts than the Ni/SBA-15 sample, in contrast to Ni-Cu/SBA-15. Although all of the catalysts showed conversions near $100 \%$ at low TOS, the operating conditions used in this work allow to clearly observe a different loss of activity for each catalyst after $5 \mathrm{~h}$. Hence, the Ni-Cu/SBA-15 sample exhibited more marked deactivation than the rest of catalysts, while the Ni-Cr/SBA- 15 sample achieved to keep the highest glycerol conversion after $5 \mathrm{~h}$ TOS. According to the coke formation rates displayed in Table 2, the loss of activity of these materials is related to carbon deposition, as later discussed.

On the other hand, product distribution analysis indicates that all catalysts favor the glycerol steam reforming reaction with hydrogen productions above $50 \mathrm{~mol} \%$ among the product stream on a dry basis (equilibrium value $\sim 62 \mathrm{~mol} \%$ [11]). It is known that Ni-based catalysts favor the breakage of $\mathrm{C}-\mathrm{C}$ and $\mathrm{C}-\mathrm{H}$ bonds, as well as methane steam reforming and water-gas shift reactions, so that relatively high concentration of $\mathrm{CO}_{2}$ and lower amounts of $\mathrm{CO}$ and, mainly, $\mathrm{CH}_{4}$ could be found among the products. Regarding hydrogen production, the Ni-Cr/SBA- 15 catalyst exhibited the highest $\mathrm{H}_{2}$ concentration in the gas stream, in line with the high conversion achieved by this material in comparison to the rest of samples. The higher activity of Ni-Cr/SBA- 15 must be ascribed to the promoting effect obtained by $\mathrm{Cr}$ incorporation in the formulation of $\mathrm{Ni} / \mathrm{SBA}-15$, which leaded to the smallest Ni crystallites (as discussed in Section 2.1) by preventing agglomeration of the Ni phase particles during the catalyst preparation.

On the contrary, the Ni-Cu/SBA-15 catalyst achieved the lowest hydrogen production, since the addition of $\mathrm{Cu}$ to Ni-based catalysts can interfere with $\mathrm{Ni}$ availability on the surface of the material, thus hindering the $\mathrm{Ni}$ activity [38]. As a consequence, higher amounts of intermediate products $\left(\mathrm{CH}_{4}\right.$ and $\left.\mathrm{CO}\right)$ and lower amounts of final products $\left(\mathrm{CO}_{2}\right.$ and $\left.\mathrm{H}_{2}\right)$ could be found for this sample. Both beneficial and unfavorable effects on the reforming activity have been published for the incorporation of $\mathrm{Cu}$ to Ni-based catalysts, depending on the $\mathrm{Cu}$ loading $[19,20,39]$. Despite the higher glycerol conversion, the Ni-Co/SBA-15 catalyst led to lower hydrogen content in the gas stream than the $\mathrm{Ni} / \mathrm{SBA}-15$ sample, which may be ascribed to the lower capacity of Co than Ni for breaking $\mathrm{C}-\mathrm{C}$ bonds [17].

In terms of coke formation, the Ni-Cr/SBA-15 catalyst exhibited the lowest value, just $13 \mathrm{mg} / \mathrm{g}_{\text {catalyst }} \cdot \mathrm{h}$. This high resistance to carbon deposition may be ascribed to the promoting effect of $\mathrm{Cr}$ on the Ni phase to form smaller particles (as found by XRD and TEM), avoiding the arrangement of large ensembles of Ni metal atoms necessary to generate the intermediary surface species in coke formation [40]. In addition, the presence of $\mathrm{Cr}$ in Ni-based catalyst has been described to increase the strength of basic sites [41], which would prevent the formation of coke precursors by dehydration reactions catalyzed by acid sites [42,43]. The low amount of coke found on the Ni-Co/SBA-15 may also be explained by the small size of the Ni phase crystallites, together with the lower capacity of Co than Ni for $\mathrm{C}-\mathrm{C}$ bonds cleavage, which makes this metal less prone to coke accumulation [17]. On the contrary, the Ni-Cu/SBA-15 sample exhibited the highest coke deposition, even higher than the reference Ni/SBA-15 material despite the slightly smaller crystallites of the Ni phase found in the $\mathrm{Cu}$-containing sample (see Table 1). This may be ascribed to the high affinity of $\mathrm{Cu}$ with graphite structures, which may facilitate the growth of carbon filaments from methane in $\mathrm{Cu}-\mathrm{Ni}$ catalysts at 
certain amounts of copper [44]. In fact, the SEM image of the used Ni-Cu/SBA-15 catalyst, displayed in Figure 7A, shows coke deposits with the morphology of carbon nanofibers among the catalyst particles. Similar types of carbon deposition can be observed for the Ni-Co/SBA-15 sample in Figure 7B, but the number of nanofibers found among the catalyst particles is significantly lower, in line with the carbon formation values displayed in Table 2. Finally, no carbon nanofiber could be found in SEM images for the Ni-Cr/SBA-15 catalyst (Figure 7C), probably due to the low carbon amount formed on this sample during the catalytic test. However, TEM analysis of this catalyst, revealed also the formation of nanofibers, as shown in Figure 7D.
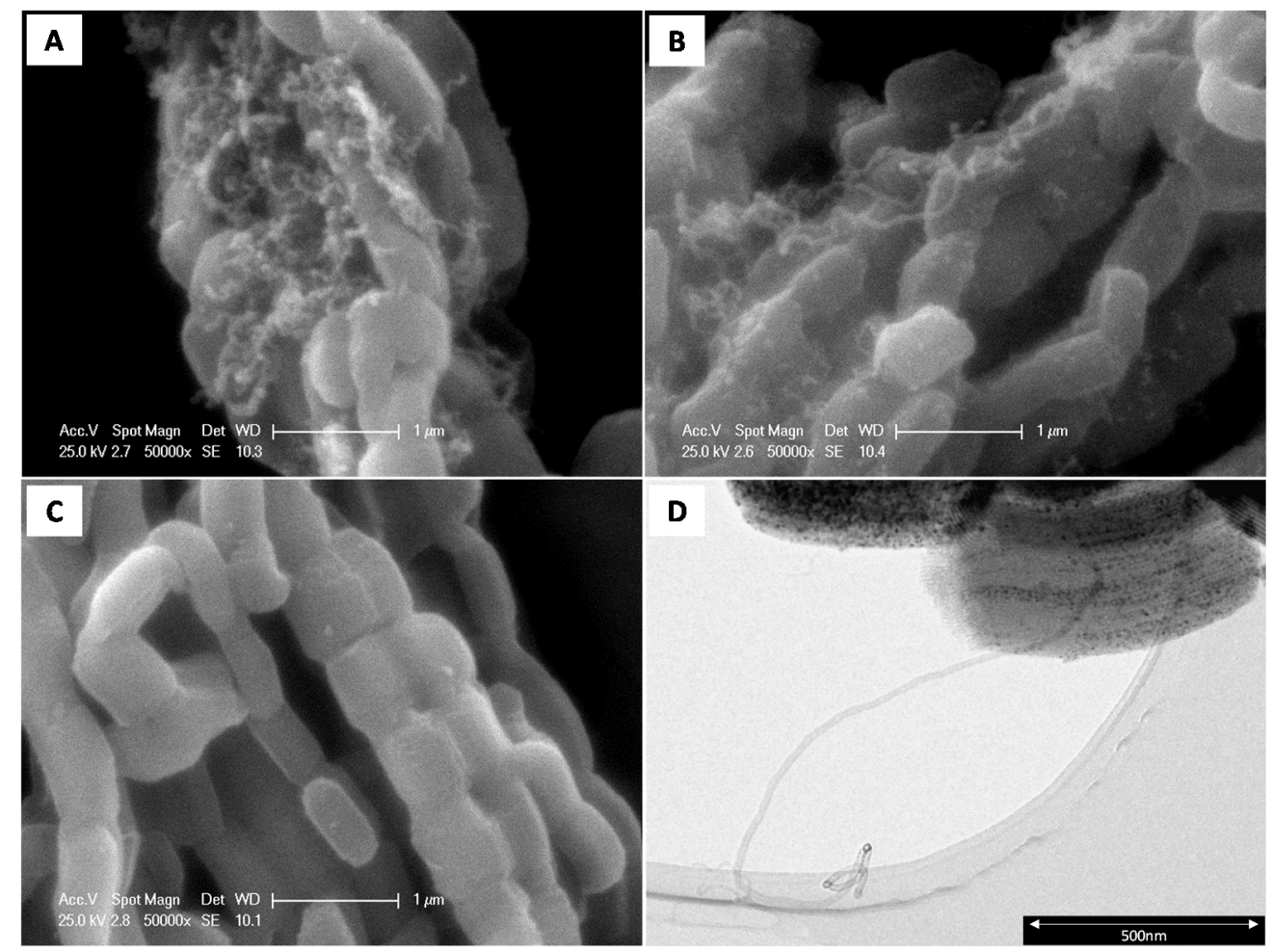

Figure 7. Micrographs of the bimetallic catalysts after $5 \mathrm{~h}$ on-stream under reaction conditions. SEM images: (A) Ni-Cu/SBA-15; (B) Ni-Co/SBA-15; and (C) Ni-Cr/SBA-15. TEM image: (D) Ni-Cr/SBA-15.

Finally, taking into account that the best results in terms of glycerol conversion and hydrogen production with reduced coke formation were obtained with the Ni-Cr/SBA-15 catalyst, a stability test was performed with this catalyst under the same operating conditions for $60 \mathrm{~h}$. The evolution of glycerol conversion and hydrogen production with TOS are shown in Figure 8. Glycerol conversion above $93 \%$ was maintained after $60 \mathrm{~h}$ on stream, indicating relatively good stability of Ni-Cr/SBA-15 sample. However, the hydrogen content in the gas outlet stream decreased with time to reach an almost constant value around $49 \mathrm{~mol} \%$.

In general, notable catalytic performance has been obtained by the Ni-Cr/SBA- 15 catalyst in the glycerol steam reforming. Papageridis et al. [45] have recently published a very complete work where $\mathrm{Al}_{2} \mathrm{O}_{3}$-supported $\mathrm{Ni}, \mathrm{Co}$, and $\mathrm{Cu}$ catalysts were used in glycerol steam reforming at different temperatures. At $600{ }^{\circ} \mathrm{C}$, they obtained initial conversions between $89.05 \%$ and $92.05 \%$ and $\mathrm{H}_{2}$ selectivity between $54.58 \%$ and $61.04 \%$ (depending on the catalyst), using a $\mathrm{H}_{2} \mathrm{O} /$ glycerol of 20 and a WHSV $\mathrm{Wlycerol}_{\text {of }}$ ca. $7.2 \mathrm{~h}^{-1}$. In addition, conversion dropped with time during a $20 \mathrm{~h}$ stability test. These values are lower than those reached by the Ni-Cr/SBA-15 sample in the present work $\left(\mathrm{H}_{2}\right.$ selectivity calculated as [45]: 68.1\%). For Ni- $\mathrm{ZrO}_{2} / \mathrm{CeO}_{2}$ catalyst, Dave et al. [6] obtained a glycerol of $56.4 \%$ and $\mathrm{H}_{2}$ selectivity of $73.7 \%$ at $600{ }^{\circ} \mathrm{C}$ with $\mathrm{H}_{2} \mathrm{O} /$ glycerol and $\mathrm{WHSV}_{\text {glycerol }}$ of ca. 20 and $2 \mathrm{~h}^{-1}$, respectively, which are softer reaction conditions than those used in the present study. 
On the other hand, compared to the results that we obtained with a Co/Ce/SBA-15 catalyst in a recent work [8] under the same operating conditions, the Ni-Cr/SBA-15 sample achieved lower conversion and hydrogen production, but also lower carbon deposition. Thus, it would be interesting to study better catalyst formulations, for example, by adding other elements, e.g., Ce, to the support of $\mathrm{Ni}-\mathrm{Cr} / \mathrm{SBA}-15$ catalyst.

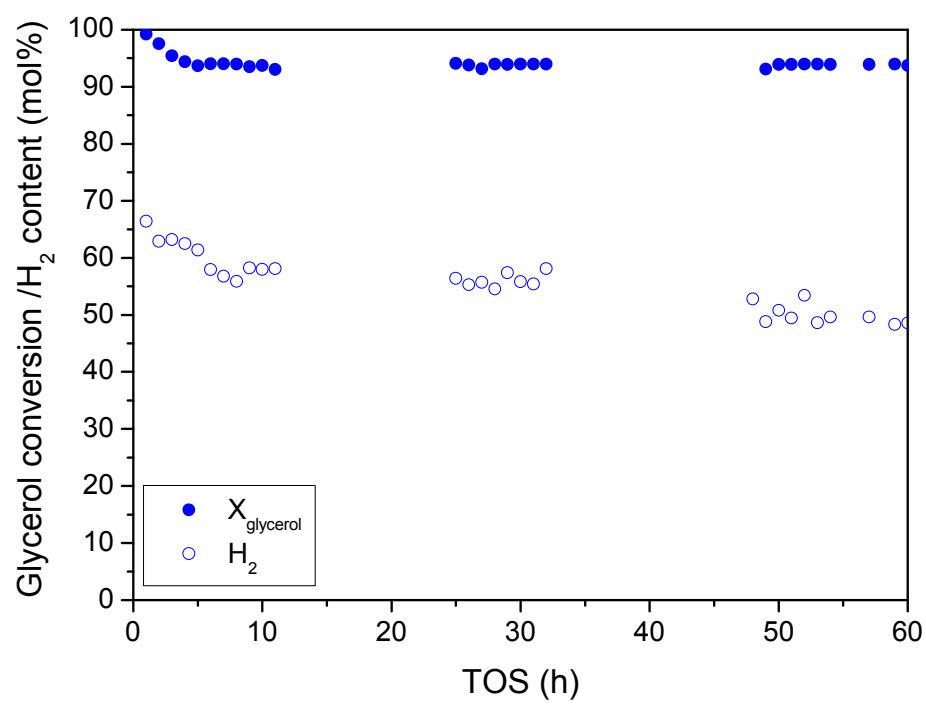

Figure 8. Evolution of glycerol conversion and hydrogen production with time-on-stream during stability test using Ni-Cr $/ \mathrm{SBA}-15$ catalyst $\left(T=600^{\circ} \mathrm{C}, P=1 \mathrm{bar}, \mathrm{WHSV}_{\text {glycerol }}=7.7 \mathrm{~h}^{-1}\right.$; water $/$ glycerol $=6 \mathrm{~mol} / \mathrm{mol})$.

\section{Experimental Section}

\subsection{Catalysts Preparation}

Catalysts containing $15 \mathrm{wt} \% \mathrm{Ni}$ and $4 \mathrm{wt} \%$ of $\mathrm{Cu}, \mathrm{Cr}$, or Co were prepared over SBA-15 mesoporous material. The selection of these loadings was based on the literature $[19,20,27]$, taking into account known commercial and research formulations of steam reforming catalysts.

The synthesis of SBA-15 was carried out by the hydrothermal method as described elsewhere [17]. Subsequent air-calcination at $550{ }^{\circ} \mathrm{C}$ under static conditions for $5 \mathrm{~h}$ at a heating rate of $1.8^{\circ} \mathrm{C} / \mathrm{min}$ was carried out to eliminate the template agent. During the preliminary experiments (not included in the manuscript), we proved that simultaneous incorporation of the metals led to better catalytic properties of the materials in comparison to sequential addition. Therefore, addition of metals to the calcined SBA-15 was carried out by incipient wetness co-impregnation using aqueous solutions of the metallic precursors, $\mathrm{Ni}\left(\mathrm{NO}_{3}\right)_{2} \cdot 6 \mathrm{H}_{2} \mathrm{O}$ (Sigma-Aldrich, St. Louis, $\mathrm{MO}, \mathrm{USA}$ ), $\mathrm{Co}\left(\mathrm{NO}_{3}\right)_{2} \cdot 6 \mathrm{H}_{2} \mathrm{O}$ (Sigma-Aldrich, St. Louis, MO, USA), $\mathrm{Cr}\left(\mathrm{NO}_{3}\right) \cdot \mathrm{H}_{2} \mathrm{O}$, or $\mathrm{Cu}\left(\mathrm{NO}_{3}\right)_{3} \cdot 4 \mathrm{H}_{2} \mathrm{O}$ (Scharlab, Sentmenat, Barcelona, Spain) with the proper concentration to obtain the desired loadings in the final catalysts, and subsequent air-calcination at $600{ }^{\circ} \mathrm{C}$. A catalyst containing only $\mathrm{Ni}$ was prepared as the reference material, following the above-described procedure. Catalysts were named as Ni/SBA-15, Ni-Co/SBA-15, Ni-Cu/SBA-15, and Ni-Cr/SBA-15.

\subsection{Catalyst Characterization}

Catalysts were characterized by inductively coupled plasma atomic emission spectroscopy (ICP-AES), X-ray powder diffraction (XRD), hydrogen temperature programmed reduction $\left(\mathrm{H}_{2}-\mathrm{TPR}\right)$, nitrogen physisorption analysis, and transmission electron microscopy (TEM). 
The ICP-AES technique was used to determine the actual metal content in the catalysts. Analyses of the samples, previously dissolved by acidic digestion with $\mathrm{H}_{2} \mathrm{SO}_{4}$ and $\mathrm{HF}$, were performed on a Varian (Palo Alto, CA, USA) VISTA-PRO AX CCD simultaneous ICP-AES apparatus.

$\mathrm{XRD}$ was used to determine the mesostructure of the prepared materials and the crystalline phases in the catalysts (according to the JCPDS index), as well as the mean crystallites diameters calculated by Scherrer equation. Data were acquired on a Philips (Eindhoven, The Netherlands) X'Pert $\mathrm{PRO}$ diffractometer, using $\mathrm{Cu} \mathrm{K} \alpha$ radiation, a $2 \theta$ increment step of $0.020^{\circ}$, and a collection time of $2 \mathrm{~s}$.

$\mathrm{H}_{2}$-TPR was used to analyze the reducibility of the samples and obtain information about metal-support interaction. Measurements of the samples were performed on a Micromeritics (Norcross, GA, USA) AUTOCHEM 2910, placing the catalyst in a fixed-bed quartz tube under $10 \% \mathrm{H}_{2}$ in argon flow ( $35 \mathrm{~mL} / \mathrm{min}$ ) with a heating rate of $5{ }^{\circ} \mathrm{C} / \mathrm{min}$ from 25 to $900{ }^{\circ} \mathrm{C}$. Effluent gas is forced to flow through a cold trap to remove water produced before reaching the thermal conductivity detector (TCD). Samples were previously degasified under dry argon flow $(35 \mathrm{~mL} / \mathrm{min})$ at $110^{\circ} \mathrm{C}$ for $30 \mathrm{~min}$ with a heating rate of $15^{\circ} \mathrm{C} / \mathrm{min}$.

Textural properties were measured by $\mathrm{N}_{2}$ adsorption/desorption analyses at $77 \mathrm{~K}$, using a Micromeritics (Norcross, GA, USA) TRISTAR 3000 sorptometer. Prior to the nitrogen-adsorption, samples were outgassed under vacuum at $200{ }^{\circ} \mathrm{C}$ for $4 \mathrm{~h}$. Surface areas were calculated according to the Brunauer-Emmett-Teller (BET) method.

The morphology of the catalysts particles was observed by TEM. Micrographs were obtained on a Philips (Eindhoven, The Netherlands) TECNAI 20 microscope equipped with $\mathrm{W}$ filament and an accelerating voltage of $200 \mathrm{kV}$, with a point-to-point resolution of $0.27 \mathrm{~nm}$. The apparatus has also the possibility to perform elemental microanalysis by energy dispersive $\mathrm{X}$-ray spectroscopy (EDX). Samples were prepared by powder dispersion of the material, finely divided, in acetone and subsequently deposited on a gold grid with a carbon support.

\subsection{Catalytic Test}

The experimental installation where steam reforming test were accomplished was a MICROACTIVITY-PRO unit (PID Eng\&Tech, Alcobendas, Madrid, Spain) as described elsewhere [7]. A schematic diagram of this setup is shown in Figure 9.

The catalyst, around $300 \mathrm{mg}$, was placed in the tubular reactor (i.d. $=9.2 \mathrm{~mm}, L=300 \mathrm{~mm}$ ) made in stainless steel 316. Previous to the reaction, the catalyst was reduced in situ under flowing pure hydrogen $(30 \mathrm{~mL} / \mathrm{min})$ at $700{ }^{\circ} \mathrm{C}$ for $0.5 \mathrm{~h}$ with a heating rate of $2{ }^{\circ} \mathrm{C} / \mathrm{min}$. For comparative purposes, all of the catalysts were activated under the same conditions, trying to avoid the influence of the activation step on the catalytic performance. After the catalyst activation, the reaction temperature was fixed for each experiment at $600{ }^{\circ} \mathrm{C}$ and the catalytic test was carried out isothermally at atmospheric pressure under nitrogen-diluted conditions. A liquid reaction mixture with water/glycerol molar ratio $=6$ was introduced at a flow rate of $0.075 \mathrm{~mL} / \mathrm{min}$, vaporized at $200{ }^{\circ} \mathrm{C}$ and further eluted by $\mathrm{N}_{2}(60 \mathrm{~mL} / \mathrm{min})$. Weight hourly space velocity (WHSV), defined as the ratio between the inlet feed mass flow rate and the mass of catalyst, was $\mathrm{WHSV}_{\text {glycerol }}=7.7 \mathrm{~h}^{-1}$. The composition of the output gas stream was determined online in an Agilent (Santa Clara, CA, USA) 490 Micro-GC equipped with a PoraPlot $\mathrm{U}$ column $(10 \mathrm{~m})$, a molecular sieve $5 \mathrm{~A}$ column $(20 \mathrm{~m})$ and a thermal conductivity detector (TCD). Condensable vapors were trapped in the condenser at $4{ }^{\circ} \mathrm{C}$ and analyzed in a Varian (Palo Alto, CA, USA) CP-3900 chromatograph equipped with a CP-WAX $52 \mathrm{CB}(30 \mathrm{~m} \times 0.25 \mathrm{~mm}, \mathrm{DF}=0.25)$ column and flame ionization detector (FID).

Glycerol conversion was calculated as follows:

$$
X(\mathrm{~mol} \%)=\frac{F_{\text {in }}-F_{\text {out }}}{F_{\text {in }}} \cdot 100,
$$

where $F_{\text {in }}$ and $F_{\text {out }}$ are the molar flow rates of glycerol at the inlet and outlet of the reactor, respectively, The products outlet stream was analyzed several times along time on stream (TOS). 
Carbon deposited during catalytic tests was evaluated by thermogravimetric analyses (TGA) performed in air flow $\left(100 \mathrm{Ncm}^{3} / \mathrm{min}\right)$ on a TA Instruments (New Castle, DE, USA) SDT 2960 thermobalance, with a heating rate of $5^{\circ} \mathrm{C} / \mathrm{min}$ up to $800{ }^{\circ} \mathrm{C}$.

In order to analyze the morphology of carbon deposits formed on used catalysts, scanning electron microscopy (SEM) was performed on a Philips (Eindhoven, The Netherlands) XL30 Environmental Scanning Electron Microscope equipped with a tungsten filament and an accelerating voltage of $25 \mathrm{kV}$.

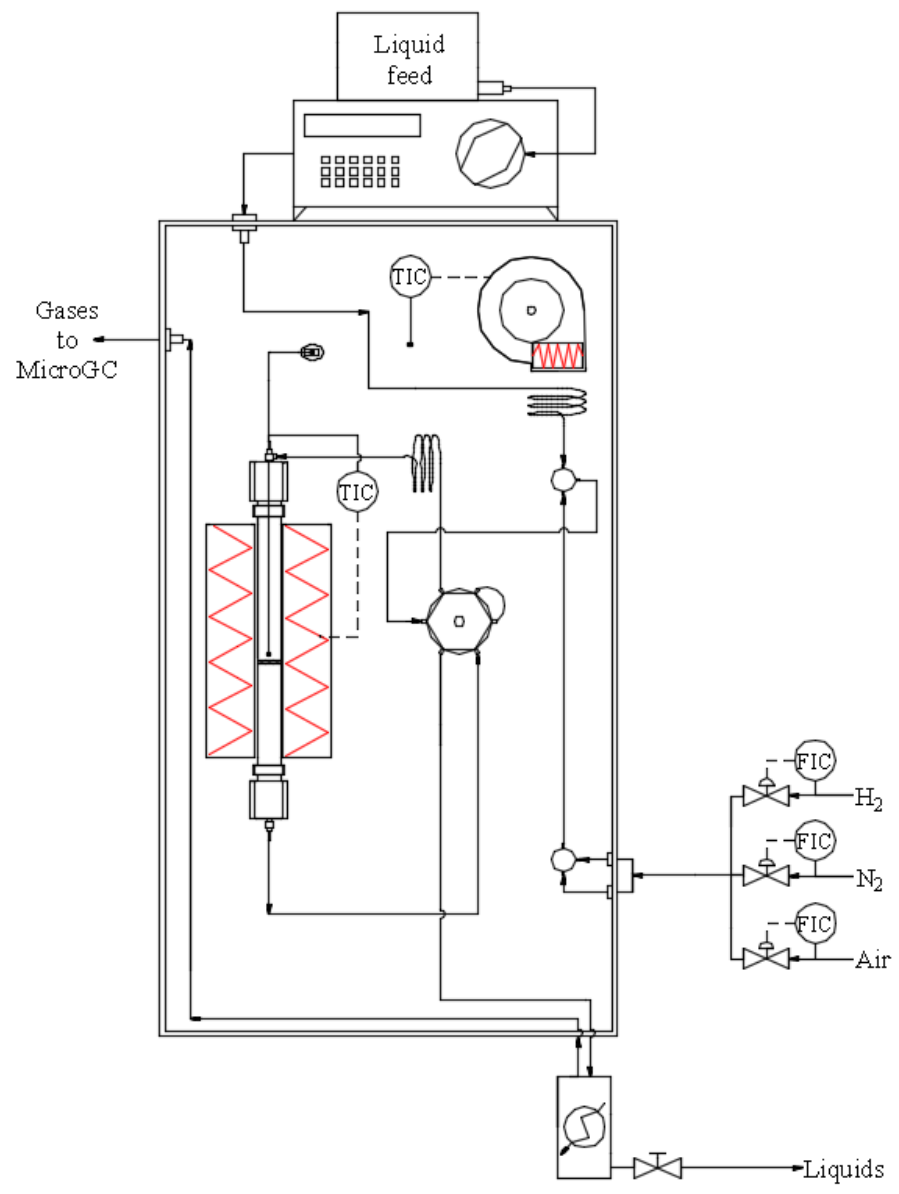

Figure 9. Schematic diagram of the reaction system.

\section{Conclusions}

The effect of adding $\mathrm{Cu}, \mathrm{Co}$, and $\mathrm{Cr}$ to the formulation of Ni/SBA-15 catalysts for hydrogen production by glycerol steam reforming has been studied. The presence of these additional metals in the catalyst helps to form smaller crystallites of the Ni phase, mainly in the case of the Ni-Cr/SBA-15 sample. The incorporation of $\mathrm{Co}$, and especially $\mathrm{Cu}$, to Ni/SBA-15 led to the development of metal oxide species with lower reduction temperatures, while the Ni-Cr/SBA-15 sample exhibited a broad reduction profile at high temperatures with features above $500{ }^{\circ} \mathrm{C}$, ascribed to the reduction of amorphous dispersive nickel oxide species. As a consequence, the best results in terms of glycerol conversion and hydrogen production were obtained with the Ni-Cr/SBA- 15 catalyst at $600{ }^{\circ} \mathrm{C}$, which also achieved a reduction in coke formation by almost six times compared to the Ni/SBA-15 material.

Acknowledgments: The authors acknowledge the financial support from the "Comunidad Autónoma de Madrid" through the RESTOENE2 project (S2013/MAE-2882) and from the "Ministerio de Economía y Competitividad" through the project CTQ2013-44447-R. 
Author Contributions: J.A.C. and A.C. conceived this work and designed the experiments. L.G.-M. performed the experimental work and wrote a draft manuscript. A.J.V. analyzed the data and wrote the paper. J.A.C. and A.C. revised the final version of the paper.

Conflicts of Interest: The authors declare no conflict of interest.

\section{References}

1. European Commission. The European Union Leading in Renewables. 2015. Available online: http://ec. europa.eu/energy/sites/ener/files/documents/cop21-brochure-web.pdf (accessed on 2 November 2016).

2. International Energy Agency. Hydrogen Production and Storage: RED Priorities and Gaps; IEA Publications: Paris, France, 2006.

3. Vizcaíno, A.J.; Carrero, A.; Calles, J.A. Hydrogen Production from Bioethanol. In Hydrogen Production: Prospects and Processes; Honnery, D.R., Moriarty, P., Eds.; Nova Science Publishers, Inc.: New York, NY, USA, 2012; pp. 247-294.

4. Gómez-Sainero, L.M.; Baker, R.T.; Vizcaíno, A.J.; Francis, S.M.; Calles, J.A.; Metcalfe, I.S.; Rodríguez, J.J. Steam reforming of methanol with $\mathrm{Sm}_{2} \mathrm{O}_{3}-\mathrm{CeO}_{2}$-supported palladium catalysts: Influence of the thermal treatments of catalyst and support. Ind. Eng. Chem. Res. 2009, 48, 8364-8372. [CrossRef]

5. Calles, J.A.; Carrero, A.; Vizcaíno, A.J.; Lindo, M. Effect of Ce and $\mathrm{Zr}$ addition to $\mathrm{Ni} / \mathrm{SiO}_{2}$ catalysts for hydrogen production through ethanol steam reforming. Catalysts 2015, 5, 58-76. [CrossRef]

6. Dave, C.D.; Pant, K.K. Renewable hydrogen generation by steam reforming of glycerol over zirconia promoted ceria supported catalyst. Renew. Energy 2011, 36, 3195-3202. [CrossRef]

7. Calles, J.A.; Carrero, A.; Vizcaíno, A.J.; García-Moreno, L. Hydrogen production by glycerol steam reforming over SBA-15-supported nickel catalysts: Effect of alkaline earth promoters on activity and stability. Catal. Today 2014, 227, 198-206. [CrossRef]

8. Carrero, A.; Vizcaíno, A.J.; Calles, J.A.; García-Moreno, L. Hydrogen production through glycerol steam reforming using Co catalysts supported on SBA-15 doped with Zr, Ce and La. J. Energy Chem. 2017, 26, 42-48. [CrossRef]

9. Quispe, C.A.G.; Coronado, C.J.R.; Carvalho, J.A., Jr. Glycerol: Production, consumption, prices, characterization and new trends in combustion. Renew. Sustain. Energy Rev. 2013, 27, 475-493. [CrossRef]

10. Anitha, M.; Kamarudina, S.K.; Kofli, N.T. The potential of glycerol as a value-added commodity. Chem. Eng. J. 2016, 295, 119-130. [CrossRef]

11. Wang, X.; Li, M.; Li, S.; Wang, H.; Wang, S.; Ma, X. Hydrogen production by glycerol steam reforming with/without calcium oxide sorbent: A comparative study of thermodynamic and experimental work. Fuel Process. Technol. 2010, 91, 1812-1818. [CrossRef]

12. Silva, J.M.; Soria, M.A.; Madeira, L.M. Challenges and strategies for optimization of glycerol steam reforming process. Renew. Sustain. Energy Rev. 2015, 42, 1187-1213. [CrossRef]

13. Lin, Y.-C. Catalytic valorization of glycerol to hydrogen and syngas. Int. J. Hydrog. Energy 2013, 38, 2678-2700. [CrossRef]

14. Delparish, A.; Avci, A.K. Intensified catalytic reactors for Fischer-Tropsch synthesis and for reforming of renewable fuels to hydrogen and synthesis gas. Fuel Process. Technol. 2016, 151, 72-100. [CrossRef]

15. Ni, M.; Leung, D.Y.C.; Leung, M.K.H. A review on reforming bio-ethanol for hydrogen production. Int. J. Hydrog. Energy 2007, 32, 3238-3247. [CrossRef]

16. Said, S.A.M.; Waseeuddin, M.; Simakov, D.S.A. A review on solar reforming systems. Renew. Sustain. Energy Rev. 2016, 59, 149-159. [CrossRef]

17. Vizcaíno, A.J.; Carrero, A.; Calles, J.A. Comparison of ethanol steam reforming using Co and Ni catalysts supported on SBA-15 modified by Ca and Mg. Fuel Process. Technol. 2016, 146, 99-109. [CrossRef]

18. Tuan, L.A.; Luong, N.T.; Ishihara, K.N. Low-temperature catalytic performance of Ni-Cu/ $\mathrm{Al}_{2} \mathrm{O}_{3}$ catalysts for gasoline reforming to produce hydrogen applied in spark ignition engines. Catalysts 2016, 6, 45-61. [CrossRef]

19. Vizcaíno, A.J.; Carrero, A.; Calles, J.A. Hydrogen production by ethanol steam reforming over Cu-Ni supported catalysts. Int. J. Hydrog. Energy 2007, 32, 1450-1461. [CrossRef] 
20. Carrero, A.; Calles, J.A.; Vizcaíno, A.J. Hydrogen production by ethanol steam reforming over Cu-Ni/SBA-15 supported catalysts prepared by direct synthesis and impregnation. Appl. Catal. A Gen. 2007, 327, 82-94. [CrossRef]

21. Hossain, M.M.; de Lasa, H.I. Reactivity and stability of $\mathrm{Co}-\mathrm{Ni} / \mathrm{Al}_{2} \mathrm{O}_{3}$ oxygen carrier in multicycle CLC. AIChE. J. 2007, 53, 1817-1829. [CrossRef]

22. Shen, J.-H.; Chen, Y.-W. Catalytic properties of bimetallic NiCoB nanoalloy catalysts for hydrogenation of p-chloronitrobenzene. J. Mol. Catal. A Chem. 2007, 273, 265-276. [CrossRef]

23. Assaf, P.G.M.; Nogueira, F.G.E.; Assaf, E.M. Ni and Co catalysts supported on alumina applied to steam reforming of acetic acid: Representative compound for the aqueous phase of bio-oil derived from biomass. Catal. Today 2013, 213, 2-8. [CrossRef]

24. Djinovi, P.; Gasan, I.; Crnivec, O.; Erjavec, B.; Pintar, A. Influence of active metal loading and oxygen mobility on coke-free dry reforming of Ni-Co bimetallic catalysts. Appl. Catal. B Environ. 2012, 125, 259-270. [CrossRef]

25. Xu, J.; Zhou, W.; Li, Z.; Wang, J.; Ma, J. Biogas reforming for hydrogen production over nickel and cobalt bimetallic catalysts. Int. J. Hydrog. Energy 2009, 34, 6646-6654. [CrossRef]

26. Zhao, M.; Church, T.L.; Harris, A.T. SBA-15 supported Ni-Co bimetallic catalysts for enhanced hydrogen production during cellulose decomposition. Appl. Catal. B Environ. 2011, 101, 522-530. [CrossRef]

27. García, L.; French, R.; Czernik, S.; Chornet, E. Catalytic steam reforming of bio-oils for the production of hydrogen: Effects of catalyst composition. Appl. Catal. A Gen. 2000, 201, 225-239. [CrossRef]

28. Wang, J.B.; Kuo, L.; Huang, T. Study of carbon dioxide reforming of methane over bimetallic $\mathrm{Ni}-\mathrm{Cr} /$ yttria-doped ceria catalysts. Appl. Catal. A Gen. 2003, 249, 93-105. [CrossRef]

29. Argyle, M.D.; Bartholomew, C.H. Heterogeneous catalyst deactivation and regeneration: A review. Catalysts 2015, 5, 145-269. [CrossRef]

30. Lindo, M.; Vizcaíno, A.J.; Calles, J.A.; Carrero, A. Ethanol steam reforming on Ni/Al-SBA-15 catalysts: Effect of the aluminium content. Int. J. Hydrog. Energy 2010, 35, 5895-5901. [CrossRef]

31. Van Grieken, R.; Calleja, G.; Stucky, G.D.; Melero, J.A.; García, R.A.; Iglesias, J. Supercritical fluid extraction of a nonionic surfactant template from SBA-15 materials and consequences on the porous structure. Langmuir 2003, 19, 3966-3973. [CrossRef]

32. Yang, X.; Wang, Y.; Wang, Y. Significantly improved catalytic performance of Ni-based MgO catalyst in steam reforming of phenol by inducing mesostructure. Catalysts 2015, 5, 1721-1736. [CrossRef]

33. Rossetti, I.; Gallo, A.; Dal Santo, V.; Bianchi, C.L.; Nichele, V.; Signoretto, M.; Finocchio, E.; Ramis, G.; Di Michele, A. Nickel catalysts supported over $\mathrm{TiO}_{2}, \mathrm{SiO}_{2}$ and $\mathrm{ZrO}_{2}$ for the steam reforming of glycerol. ChemCatChem 2013, 5, 294-306. [CrossRef]

34. Nichele, V.; Signoretto, M.; Menegazzo, F.; Gallo, A.; Dal Santo, V.; Cruciani, G.; Cerrato, G. Glycerol steam reforming for hydrogen production: Design of Ni supported catalysts. Appl. Catal. B Environ. 2012, 111-112, 225-232. [CrossRef]

35. Michorczyk, P.; Ogonowski, J.; Zeńczak, K. Activity of chromium oxide deposited on different silica supports in the dehydrogenation of propane with $\mathrm{CO}_{2}$-A comparative study. J. Mol. Catal. A Chem. 2011, 349, 1-12. [CrossRef]

36. Luo, N.; Ouyang, K.; Cao, F.; Xiao, T. Hydrogen generation from liquid reforming of glycerin over Ni-Co bimetallic catalyst. Biomass Bioenergy 2010, 34, 489-495. [CrossRef]

37. Yun, D.; Baek, J.; Choi, Y.; Kim, W.; Lee, H.J.; Yi, J. Promotional effect of Ni on a $\mathrm{CrO}_{x}$ catalyst supported on silica in the oxidative dehydrogenation of propane with $\mathrm{CO}_{2}$. ChemCatChem 2012, 4, 1952-1959. [CrossRef]

38. Thyssen, V.V.; Maia, T.A.; Assaf, E.M. Cu and Ni Catalysts supported on $\gamma-\mathrm{Al}_{2} \mathrm{O}_{3}$ and $\mathrm{SiO}_{2}$ assessed in glycerol steam reforming reaction. J. Braz. Chem. Soc. 2015, 26, 22-31.

39. Zhang, L.; Liu, J.; Li, W.; Guo, C.; Zhang, J. Ethanol steam reforming over Ni-Cu/ $\mathrm{Al}_{2} \mathrm{O}_{3}-\mathrm{M}_{y} \mathrm{O}_{z}(M=\mathrm{Si}, \mathrm{La}$, $\mathrm{Mg}$, and $\mathrm{Zn}$ ) catalysts. J. Nat. Gas Chem. 2009, 18, 55-65. [CrossRef]

40. Trimm, D.L. Coke formation and minimisation during steam reforming reactions. Catal. Today 1997, 37, 233-238. [CrossRef]

41. Choi, B.K.; Park, Y.H.; Moon, D.J.; Park, N.C.; Kim, Y.C. Effect of bimetallic Ni-Cr catalysts for steam-CO reforming of methane at high pressure. J. Nanosci. Nanotechnol. 2015, 15, 5259-5263. [CrossRef] [PubMed]

42. Vizcaíno, A.J.; Carrero, A.; Calles, J.A. Ethanol steam reforming on Mg- and Ca-modified Cu-Ni/SBA-15 catalysts. Catal. Today 2009, 146, 63-70. [CrossRef] 
43. Carrero, A.; Calles, J.A.; Vizcaíno, A.J. Effect of $\mathrm{Mg}$ and $\mathrm{Ca}$ addition on coke deposition over Cu-Ni/SiO 2 catalysts for ethanol steam reforming. Chem. Eng. J. 2010, 163, 395-402. [CrossRef]

44. Ashok, J.; Subrahmanyam, M.; Venugopal, A. Hydrotalcite structure derived Ni-Cu-Al catalysts for the production of $\mathrm{H}_{2}$ by $\mathrm{CH}_{4}$ decomposition. Int. J. Hydrog. Energy 2008, 33, 2704-2713. [CrossRef]

45. Papageridis, K.N.; Siakavelas, G.; Charisiou, N.D.; Avraam, D.G.; Tzounis, L.; Kousi, K.; Goula, M.A. Comparative study of $\mathrm{Ni}, \mathrm{Co}, \mathrm{Cu}$ supported on $\gamma$-alumina catalysts for hydrogen production via the glycerol steam reforming reaction. Fuel Process. Technol. 2016, 152, 156-175. [CrossRef] 